\title{
Inhibition of the DNA-binding activity of Drosophila Suppressor of Hairless and of its human homolog, KBF2/RBP-Jк, by direct protein-protein interaction with Drosophila Hairless
}

\author{
Christel Brou, ${ }^{1,5}$ Frédérique Logeat, ${ }^{1,5}$ Magalie Lecourtois, ${ }^{2}$ Joël Vandekerckhove, ${ }^{3}$ \\ Philippe Kourilsky, ${ }^{4}$ François Schweisguth, ${ }^{2}$ and Alain Israël ${ }^{1,6}$ \\ ${ }^{1}$ Unité de Biologie Moléculaire de l'Expression Génique, URA 1149 Centre National de la Recherche Scientifique (CNRS), \\ Institut Pasteur, 75724 Paris cedex 15, France; ${ }^{2}$ Institut Jacques Monod, CNRS Université Paris VII, 75251 Paris cedex 05, \\ France; ${ }^{3}$ Laboratorium voor Genetica, Rijksuniversiteit Gent, B-9000 Gent, Belgium; ${ }^{4}$ Unité de Biologie Moléculaire du \\ Gène, U. 277 Institut National de la Santé et de la Recherche Médicale (INSERM), Institut Pasteur, \\ 75724 Paris cedex 15, France
}

We have purified the sequence-specific DNA-binding protein KBF2 and cloned the corresponding cDNA, which is derived from the previously described $R B P-J \kappa$ gene, the human homolog of the Drosophila Suppressor of Hairless [ $\mathrm{Su}(\mathrm{H})]$ gene. Deletion studies of the RBP-JK and $\mathrm{Su}(\mathrm{H})$ proteins allowed us to define a DNA-binding domain conserved during evolution. Because $S u(H)$ mutant alleles exhibit dose-sensitive interactions with Hairless $(H)$ loss-of-function mutations, we have investigated whether the RBP-JK or Su(H) proteins directly interact with the $\mathrm{H}$ protein in vitro. We show here that $\mathrm{H}$ can inhibit the DNA binding of both $\mathrm{Su}(\mathrm{H})$ and $\mathrm{RBP}-\mathrm{J \kappa}$ through direct protein-protein interactions. Consistent with this in vitro inhibitory effect, transcriptional activation driven by $\mathrm{Su}(\mathrm{H})$ in transfected Drosophila $\mathrm{S2}$ cells is inhibited by $\mathrm{H}$. These results support a model in which $\mathrm{H}$ acts, at least in part, as a negative regulator of $\mathrm{Su}(\mathrm{H})$ activity. This model offers a molecular view to the antagonistic activities encoded by the $H$ and $S u(H)$ genes for the control of sensory organ cell fates in Drosophila. We further propose that a similar mechanism might occur in mammals.

[Key Words: RBP-Jк; KBF2; $\mathrm{Su}(\mathrm{H}) ; \mathrm{H}_{\text {; }}$ protein-protein interaction; transcriptional interaction]

Received June 30, 1994; revised version accepted August 18, 1994.

The human protein KBF2 specifically binds as a monomer to various $\kappa \mathrm{B}$ sites and is present in the nuclei of all cells analyzed so far (Israël et al. 1989). We have purified this factor and isolated the corresponding cDNA. Data base searching revealed a perfect homology with proteins belonging to the RBP-Jk family. RBP-Jk was originally purified based on its specific binding to the recombination signal of the Jk immunoglobulin gene (Hamaguchi et al. 1989; Matsunami et al. 1989). However, recent data strongly suggest that RBP-JK acts as a transcriptional regulator (Dou et al. 1994) by binding to specific DNA sites, whose consensus sequences have been determined (Tun et al. 1994), rather than as a recombinase in $V(D) I$ recombination (Hamaguchi et al. 1992).

A better understanding of $R B P$ - $/ \kappa$ function may benefit

\footnotetext{
${ }^{5}$ The first two authors contributed equally to this work. ${ }^{6}$ Corresponding author.
}

from the genetic analysis of the Drosophila RBP-IK homolog Suppressor of Hairless [Su(H)]. The murine RBP$\mathrm{J} \kappa$ and Drosophila $\mathrm{Su}(\mathrm{H})$ proteins share $82 \%$ identity and $94 \%$ similarity over most of their length (Furukawa et al. 1991; Schweisguth and Posakony 1992). Su(H) mutations were first isolated as dominant suppressors of the Hairless $(H)$ dominant, haploinsufficient loss-of-function mutations (Ashburner 1982). Detailed phenotypical studies have shown that $H$ and $\mathrm{Su}(H)$ act in an opposite manner to affect various developmental decisions (Bang et al. 1991; Bang and Posakony 1992; Schweisguth and Posakony 1992, 1994; Posakony 1994). In particular, loss-of-function mutations of $\mathrm{Su}(H)$ and $H$ have opposite effects on two successive alternative cell fate decisions during the formation of the adult sense organs. $H$ and $\mathrm{Su}(H)$ activities are first required in the larva for the determination of single sensory organ precursor (SOP) cells from groups of equipotent cells called proneural 
clusters (for review, see Ghysen and Dambly-Chaudière 1989|. $\mathrm{H}$ and $\mathrm{Su}(H)$ activities are also required later in the development of the pupa to determine the alternative cell fates adopted by two accessory cells of the mechanosensory organs (Bang et al. 1991; Schweisguth and Posakony 1994). Each of these two cell fate decisions also requires the activity of the neurogenic genes, including Notch (for reviews, see Simpson 1990; Posakony 1994). The role of the $H$ and $S u(H)$ gene products in these two Notch-mediated cell fate decisions remains to be elucidated.

$H$ encodes a novel basic $109-\mathrm{kD}$ protein (Bang and Posakony 1992; Maier et al. 1992). The biochemical activity and subcellular localization of the $\mathrm{H}$ protein are so far unknown. The lack of a clear epistatic relationship between $H$ and $\mathrm{Su}(H)$ for SOP determination has suggested that $H$ and $\mathrm{Su}(H)$ act antagonistically in the same genetic operation (Schweisguth and Posakony 1994), though the molecular mechanism underlying the genetic suppression of the $H$ phenotypes by $\mathrm{Su}(H)$ mutant alleles has not yet been investigated.

We report here that $\mathrm{Su}(\mathrm{H})$ may act as a transcriptional activator in a transient transfection assay and that $\mathrm{H}$ down-regulates transcriptional activation by $\mathrm{Su}(\mathrm{H})$ in this assay. Negative regulation by $\mathrm{H}$ appears to result from the formation of $\mathrm{H}-\mathrm{Su}(\mathrm{H})$ complexes that can prevent the in vitro binding of $\mathrm{Su}(\mathrm{H})$ to the DNA. Finally, we show that the DNA-binding activity of KBF2/RBP-Jk can likewise be regulated negatively by Drosophila $\mathrm{H}$ and that the proteins interact in vitro, as well as in vivo using the yeast two-hybrid system.

\section{Results}

Cloning and DNA-binding properties of different splicing products of the human RBP-Jк gene and Drosophila $\mathrm{Su}(\mathrm{H})$

$\mathrm{KBF} 2$ protein was purified from HeLa cells on the basis of binding to NF- $\mathrm{KB}$ sites, microsequenced, and cloned (see Materials and methods for details|. Sequencing analysis of the obtained cDNA fragment indicated that it encodes part of the conserved region of RBP-JK proteins (Amakawa et al. 1993).

The human RBP-Jk gene appears to be composed of 14 exons (named N1, 1, 1', N2, and 2-11). Four classes of cDNAs, that differ in their first exon but share exons 2-11, have been described (Amakawa et al. 1993; Dou et al. 1994; see Fig. 1). KBF2 could be encoded by any one of the four alternatively spliced RBP products already described. In this paper the cDNAs and the proteins encoded by the aPCR1, aPCR2, and aPCR3 transcripts of the RBP-J $\kappa$ gene (Amakawa et al. 1993) are called RBP1, RBP2, and RBP3, respectively (see Fig. 1).

To compare the properties of purified KBF2 to RBP1, RBP2, and RBP3, we tried to isolate their corresponding cDNAs by PCR amplification. The RBP1 and RBP3 cDNAs were obtained from a human lymphocyte cDNA library. However, we failed to isolate the RBP2 cDNA
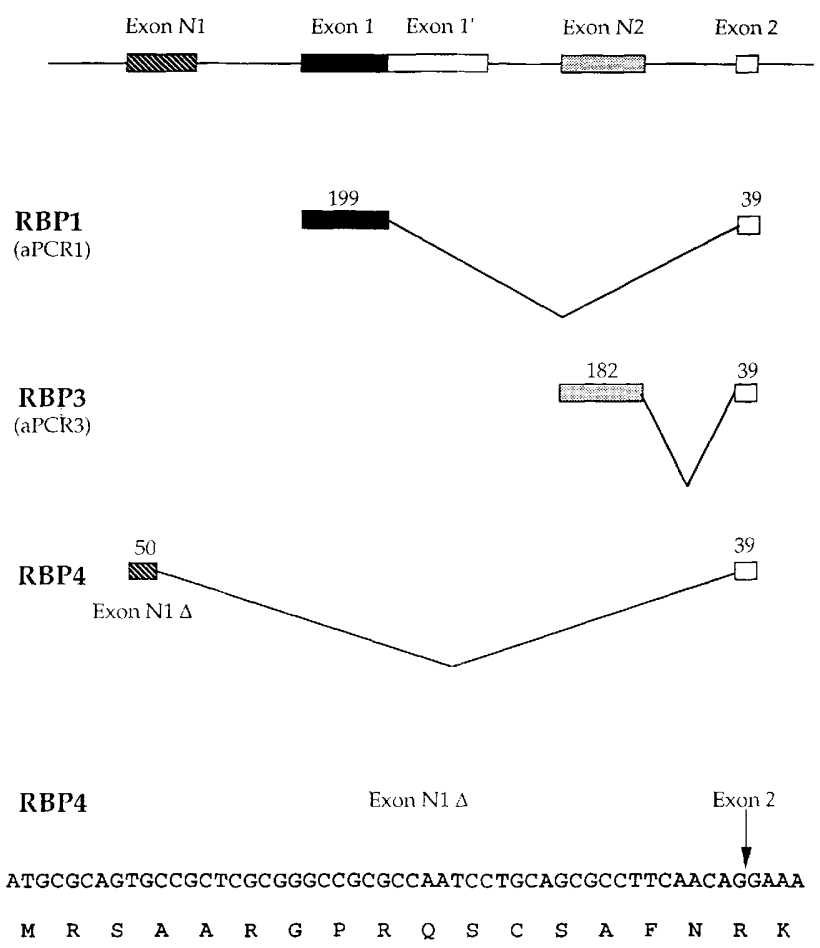

Figure 1. Schematic illustration of the three cloned cDNAs resulting from alternative splicing of the $5^{\prime}$ exons of the $R B P-/ K$ gene (exons are represented by boxes) and sequence of the exon Nl $\Delta$ of RBP4. Genomic organization of the $5^{\prime}$ exons of the gene is illustrated at the top (according to Amakawa et al. 1993). Numbering indicates exon size in base pairs.

from two different librairies or by reverse transcriptionpolymerase chain reaction (RT-PCR) from various sources of RNAs (see Materials and methods for details). A novel isoform, named RBP4, was isolated from the same library and was present in various RNA preparations (data not shown). Its sequence is shown in Figure 1. It differs from RBP2 by the use of an alternative splice donor site located within exon N1 (see Amakawa et al. 1993 for exon nomenclature).

The DNA-binding activity of KBF2/RBP-Jk was examined using a new putative RBP-binding site found in the regulatory region of the mouse Hairy Enhancer of split (HES1) gene (Akazawa et al. 1992; Sasai et al. 1992). HES1 is one of the five mammalian proteins that display structural homology with a family of Drosophila bHLH proteins encoded by neurogenic genes located in the $E n$ hancer of split $[E(s p l)]$ complex. HESl appears to be involved in neural (Ishibashi et al. 1994) as well as in muscle differentiation (Sasai et al. 1992). Our finding of a motif identical to the RBP consensus binding site, $85 \mathrm{bp}$ upstream of the transcription initiation site of the HES1 gene, was guided by the previous description of a strong in vitro RBP-binding site in the regulatory region of the Drosophila E(spl) $\mathrm{m} 8$ gene (Tun et al. 1994). A doublestranded oligonucleotide corresponding to this putative KBF2/RBP-JK-binding site (probe HES) was used in gel retardation experiments. We show here that purified 
A

competitor - - -

123
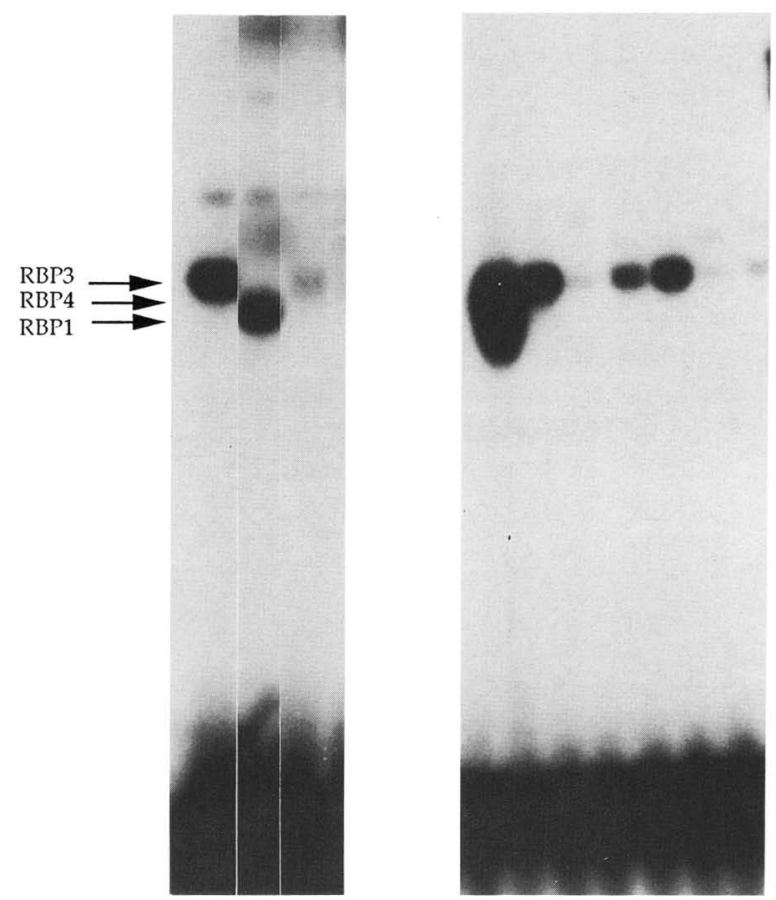

C
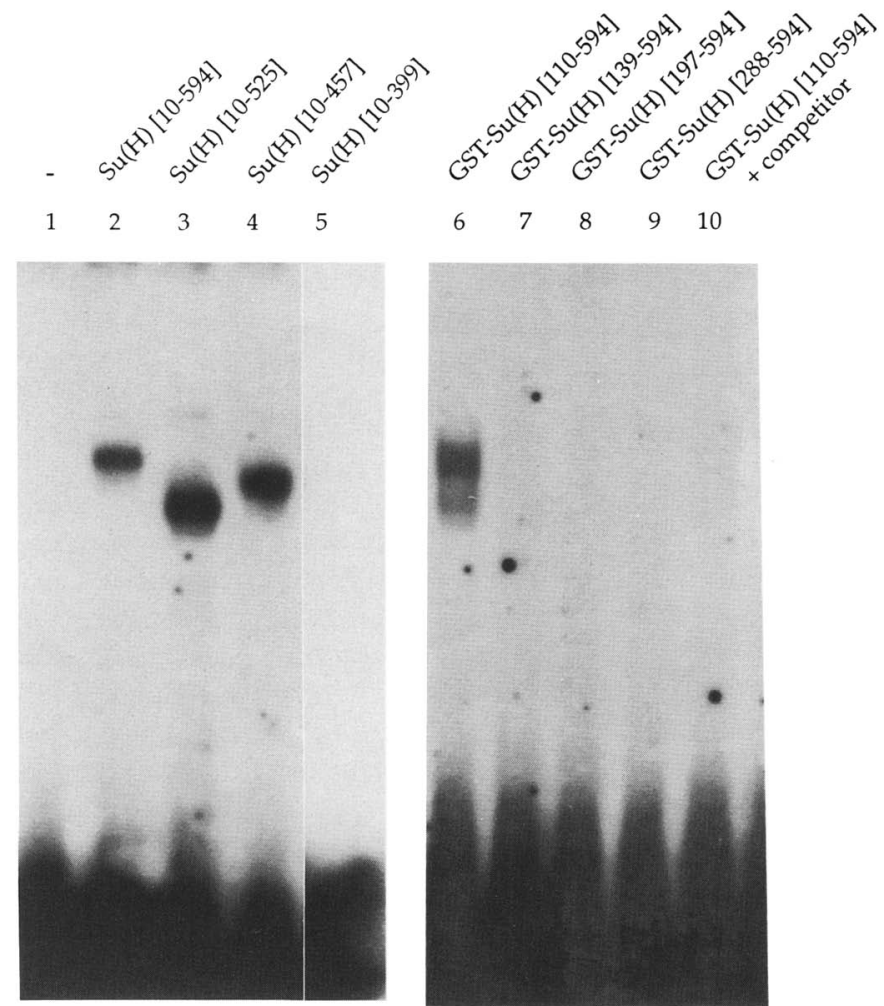

B
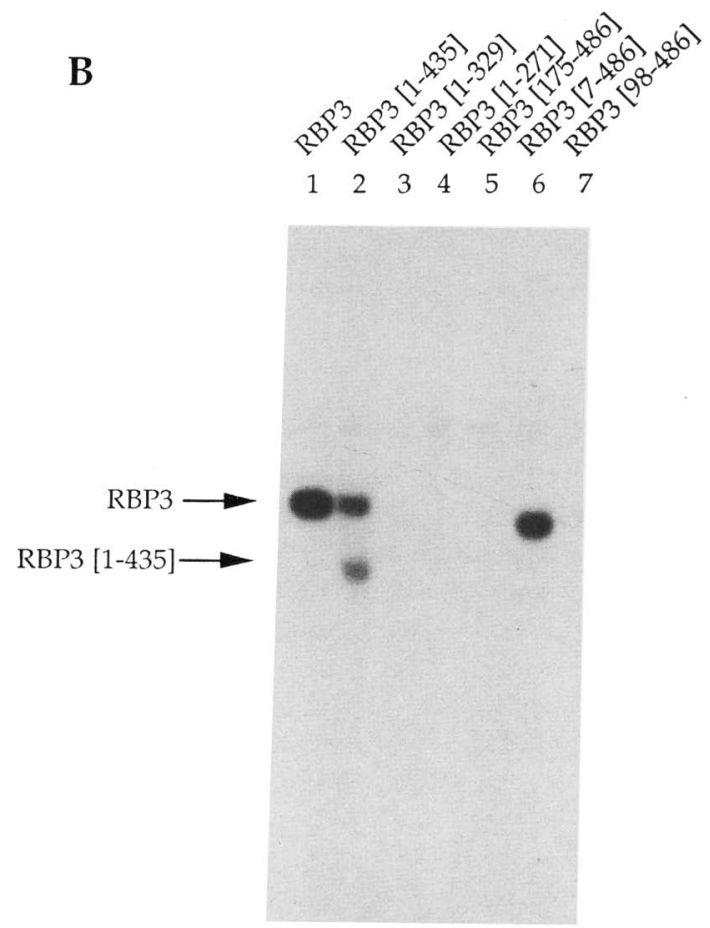

Figure 2. DNA-binding properties of the KBF2/RBP and $\mathrm{Su}(\mathrm{H})$ proteins. $(A)$ The RBP proteins have the same DNA-binding specificity as purified KBF2. The proteins encoded by the RBP1, RBP3, and RBP4 splicing products were tested for binding to the HES probe: RBP3 (lanes 1,5-10), RBP1 (lane 2), and RBP4 (lane 3) were obtained by in vitro transcription/translation in a rabbit reticulocyte lysate. Binding of RBP3 was compared with that of purified KBF2 (lane 4). As cold competitor, an excess of 300-fold of probes 2122 (lane 6), KBF (lane 7), Igк (lane 8), $\beta 2 \mathrm{~m}$ (lane 9), and кB2 (lane 10 ) was used. The arrows indicate the specific retarded band of each splicing product. $(B)$ Mapping of the DNA-binding domain of RBP3. Deletion derivatives of RBP3 were obtained by in vitro transcription/translation and tested in a gel shift experiment with the HES probe: RBP3 [1-486] (lane 1), RBP3 [1-435] (lane 2), RBP3 [1-329] (lane 3), RBP3 [1-271] (lane 4), RBP3 [175-486] (lane 5), RBP3 [7-486] (lane 6), and RBP3 [98-486] (lane 7) (see Fig. $5 \mathrm{~A}$ for a schematic representation of these constructs|. Note that the upper band in lane 2 corresponds to the full-length RBP3 translation product, because of an incomplete digestion of the template DNA. (C) Mapping of the DNA-binding domain of $\mathrm{Su}(\mathrm{H})$. Full-length and carboxy-terminal deletion derivatives of the $\mathrm{Su}(\mathrm{H})$ protein were produced in vitro in a rabbit reticulocyte lysate (lanes 1-5), whereas the amino-terminal deletion mutants were analyzed as GST fusion proteins (lanes 6-10). In all lanes, the 2122 probe was used. The relative amount of radioactively labeled $\mathrm{Su}(\mathrm{H})$ proteins was determined by PhosphorImager quantification following SDSPAGE. A similar amount of wild-type and deleted $\mathrm{Su}(\mathrm{H})$ proteins was used in each lane: $\mathrm{Su}(\mathrm{H})[10-594]$ (lane 2), $\mathrm{Su}(\mathrm{H})$ [10-525] (lane 3), $\mathrm{Su}(\mathrm{H})$ [10-457] (lane 4), $\mathrm{Su}(\mathrm{H})$ [10-399] (lane 5). In lanes 6-10, 250 ng of purified GST fusion proteins were assayed: GST$\mathrm{Su}(\mathrm{H})$ [110-594] (lanes 6,10), GST-Su(H) [139-594] (lane 7), GST-Su(H) [197-594] (lane 8), GST-Su(H) [288-594] (lane 9). As a control for specificity, a competition experiment with a 10 -fold excess of cold 2122 probe is shown in lane 10 . 
KBF2 protein (Fig. 2A, lane 4) and in vitro-translated RBP proteins (Fig. 2A, lanes 1-3,5-10) strongly bind to the HES probe (Fig. 2A). These results suggest that the HES1 promoter is a potential target for RBP binding. The KBF2 and RBP proteins also recognize the RBP-JK consensusbinding site (probe 2122) defined by Tun et al. (1994) (data not shown). Both the HES (ttactGTGGGAAagaaagt) and 2122 (gcGTGGGAAc) probes contain the core consensus sequence of 7 nucleotides, GTGGGAA, that show strong similarities to several NF-кB half-sites, including the $\beta 2$ microglobulin $(\beta 2 \mathrm{~m})$ site (aTGGGAAagtccet) used in the purification of KBF2. Formation of complexes involving either purified KBF2 (Fig. 2A, lane 4) or in vitro-translated products (lanes $1-3$ ) can be competed by several but not all NF-kB-binding sites, as well as by the consensus sequence probe (Fig. 2A, lanes 5-10; data not shown). These results are consistent with data described previously for purified RBP-JK and KBF2 proteins (Israël et al. 1989; Tun et al. 1994).

We then compared the relative DNA-binding affinities of the three isoforms, RBP1, RBP3, and RBP4, for the HES site (Fig. 2A, lanes 1-3). Whereas RBP1 and RBP3 bind with a similar affinity to the HES probe, the RBP4 product seems to bind this site poorly lequivalent quantities of each translation product were used in each lane). This indicates that the isoform-specific amino-terminal regions may contribute to RBP DNA-binding specificity.

The importance of the variable amino-terminal regions in DNA binding was investigated using a deletion construct that starts at the first amino acid common to all isoforms, the first $\mathrm{K}$ residue encoded by exon 2 (see Fig. 1) corresponding to amino acid 7 in RBP3 (see Fig. 5, below, for a schematic representation of all deletion constructs studied). As shown in Figure 2B (lane 6), RBP3 [7-486] still binds to the HES probe. We conclude that the variable amino-terminal regions of RBP are not strictly required for DNA binding. Still, the poor binding ability of RBP4 suggests that sequences encoded by the isoform-specific first exons may modulate the affinity and/or specificity of RBP binding to the DNA.

Further amino-terminal deletions within the protein sequence common to all RBP isoforms were also tested for their ability to bind the HES probe: RBP [98-486] and RBP [175-486] appear unable to bind DNA in our gel retardation assay (Fig. 2B, lanes 7 and 5, respectively). The effects of carboxy-terminal deletions, introduced in the RBP3 cDNA, were also analyzed: The RBP [1-435] construct recognized the probe (Fig. $2 B$, lane 2), whereas RBP [1-329] did not (Fig. 2B, lane 3). Thus, the region extending from exon 2 (amino acid 7 in RBP3) to amino acid 435 appears sufficient for RBP binding to the HES probe.

The Drosophila $\mathrm{Su}(\mathrm{H})$ protein was subjected to a similar deletion analysis. The nearly full-length in vitrotranslated product $(\mathrm{Su}(\mathrm{H})[10-594])$ binds specifically to the RBP consensus-binding site (probe 2122) and more weakly to the $E$ (spl) binding site identified by Tun et al. (1994) (Fig. 2C, lane 2; data not shown). Whereas the truncated $\mathrm{Su}(\mathrm{H})[10-525]$ and $\mathrm{Su}(\mathrm{H})[10-457]$ proteins were still able to bind DNA (Fig. 2C, lanes 3,4), Su(H)
[10-399] (Fig. 2C, lane 5) did not. Amino-terminal deletions were analyzed as glutathione $S$-transferase (GST) fusion proteins. A fusion protein between GST and $\mathrm{Su}(\mathrm{H})$ starting at the amino acid position 110 (corresponding to amino acid 22 in human RBP3) gave a specific gel-retarded complex (Fig. 2C, lane 6), whereas further deletions starting at amino acid 139 (corresponding to amino acid 50 in RBP3) abolished GST-Su(H) DNA binding (Fig. 2C, lanes 7-9). Thus, a region extending from amino acid positions 110-457 (22-369 in RBP3) appears necessary for $\mathrm{Su}(\mathrm{H})$ binding to the 2122 probe. These results are summarized in Figure 5A, below.

Thus, part of the Su(H)/RBP-Jk-conserved region, defined as the 425 -amino-acid region, which is $82 \%$ identical between the Drosophila and human proteins (Schweisguth and Posakony 1992; see Fig. 5A, below), does not appear to be required for DNA binding. One may speculate that this carboxy-terminal region [amino acids 458-528 and 369-439 in $\mathrm{Su}(\mathrm{H})$ and $\mathrm{RBP3}$, respectively], which has been strongly conserved during evolution, provides an interaction surface for molecules other than DNA.

\section{Direct protein-protein interaction between Drosophila $\mathrm{Su}(H)$ or human RBP3 and Drosophila $H$}

The $H$ and $S u(H)$ activities have been proposed to act antagonistically in the same genetic operation (Schweisguth and Posakony 1994). It is thus possible that $H$ and $\mathrm{Su}(\mathrm{H})$ control common downstream functions in an opposite manner. Alternatively, the $\mathrm{H}$ and $\mathrm{Su}(\mathrm{H})$ proteins may interact directly, resulting in the inhibition of either $\mathrm{H}$ or $\mathrm{Su}(\mathrm{H})$ activity. We therefore investigated whether the $\mathrm{H}$ and $\mathrm{Su}(\mathrm{H})$ proteins may interact in vitro. First, an Escherichia coli GST-Su(H) fusion protein, which contains the conserved region $\mid \mathrm{GST}-\mathrm{Su}(\mathrm{H})[110$ 594]), was tested for its ability to interact with the fulllength $\mathrm{H}$ protein synthesized in vitro in a reticulocyte lysate (Fig. 3A, lanes 1-3). As shown in Figure 3A, the $\mathrm{H}$ protein was efficiently retained on GST-Su(H) [110-594] (lane 2) but not on control GST beads (lane 3). A number of other Drosophila nuclear proteins were tested as controls and were not retained onto the GST-Su/H) $[110$ 594] beads in this assay [AEF-1 (Falb and Maniatis 1992), Daughterless (Caudy et al. 1988), Groucho (Tata and Hartley 1993), Neuralized (Price et al. 1993) (data not shown)]. Thus, the $\mathrm{H}$ and $\mathrm{Su}(\mathrm{H})$ proteins appear to be able to specifically interact in vitro under these conditions.

We then tested various $\mathrm{H}$-deletion constructs for their ability to interact in vitro with GST-Su(H) [110-594] (Figs. 3A, and 5B for a summary of the results). The first 293 amino acids appear sufficient to efficiently bind the GST-Su(H) [110-594] protein (Fig. 3A, lanes 4-6). In contrast, the $\mathrm{H}[1-236]$ in vitro translated product did not interact with GST-Su(H) [110-594] (Fig. 3A, lanes 7-9). This indicates that the $\mathrm{H}$ protein contains an interaction surface from amino acid 236 to 293, which is required for interaction with $\mathrm{Su}(\mathrm{H})$. Furthermore, this region is not sufficient for the interaction because the $\mathrm{H}[1-84 / 236-$ 


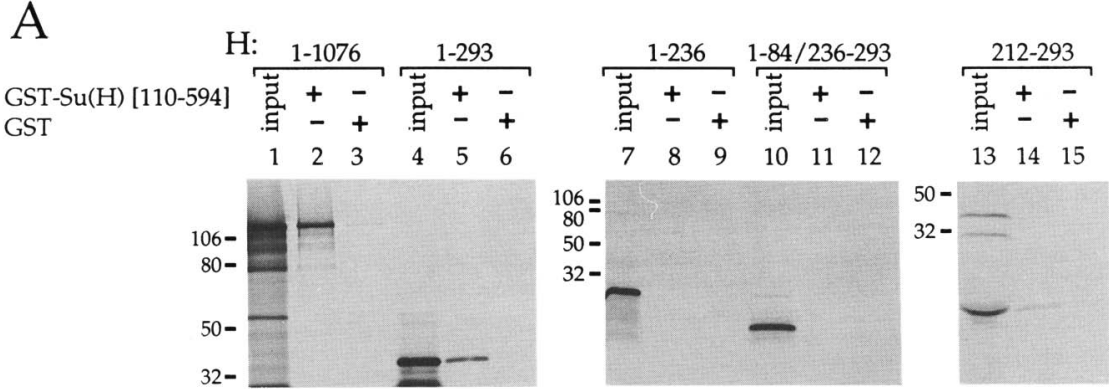

B
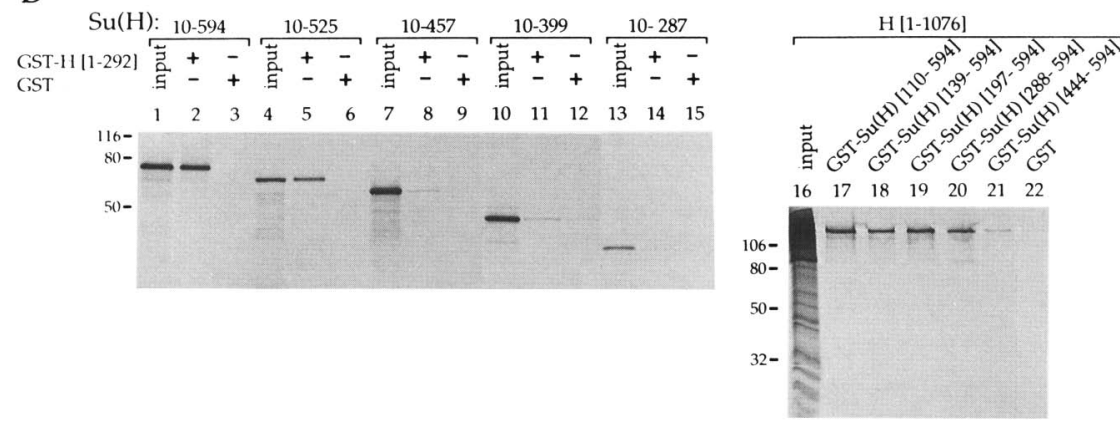

C
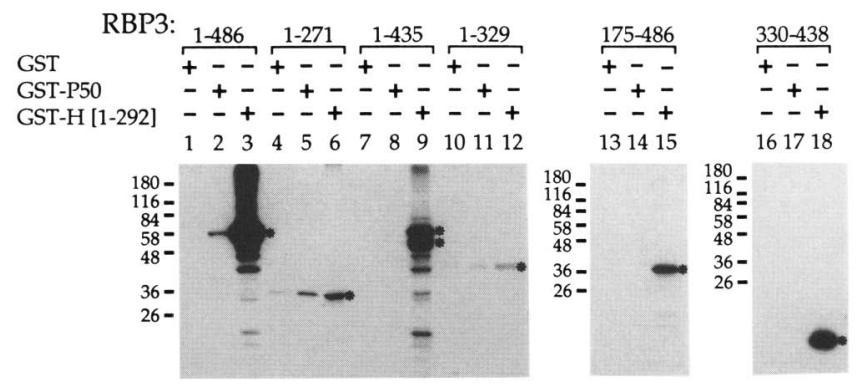

Figure 3. Direct in vitro protein-protein interaction between $\mathrm{H}$ and $\mathrm{Su}(\mathrm{H})$ or RBP3. (A) Direct protein-protein interaction between $\mathrm{Su}(\mathrm{H})$ and $\mathrm{H}$. The $\mathrm{H}[1-1076]$ and its deletion derivatives were in vitro-translated in the presence of $\left[{ }^{35} \mathrm{~S}\right] \mathrm{Met}$, and their ability to be retained onto a GST-Su(H) [110-594] fusion protein or control GST adsorbed to glutathione-agarose beads was analyzed by SDS-PAGE analysis. Molecular mass markers $(\mathrm{kD})$ are indicated at the left of each gel $(10 \%, 15 \%$, and $20 \%$ acrylamide gels are shown in lanes $1-6,7-12$, and 13-15, respectively). The input lanes $(1,4,7,10,13)$ show the different in vitro-translated products, prior to incubation with the beads. The corresponding $\mathrm{H}$ constructs are indicated above the lanes /see also Fig. 5B for a schematic representation of these constructs). The amount of $\mathrm{H}$ proteins bound to the GST-Su(H) [110-594] beads, shown in lanes $2,5,8,11$, and 14 , is compared with the control lanes $3,6,9,12$, and 15, which correspond with nonspecific binding of the same $H$ samples to GST beads. Note that identical amounts of in vitro-translated proteins are shown in the input lanes or incubated with the beads. Between $10 \%$ and $25 \%$ of the $\mathrm{H}$ [1-1076] or $\mathrm{H}$ [1-293] fraction is reproducibly retained onto the GST$\mathrm{Su}(\mathrm{H})[110-594]$, compared with the $0.5-1 \%$ background level on GST beads (lanes 1-6). Weaker binding $(5-10 \%$ of retention) is observed with the $\mathrm{H}$ [212-293] construct (lanes 13-15), whereas no specific binding is detectable with the $\mathrm{H}[1-236]$ and $[1-84 /$ 236-293] constructs (lanes 7-12). (B) Deletion mapping of the HID of $\mathrm{Su}(\mathrm{H})$. (Lanes 1-15) Carboxy-terminal truncation derivatives of $\mathrm{Su}(\mathrm{H})$ were in vitro-translated in the

presence of $\left[{ }^{35} \mathrm{~S}\right]$ Met and tested for their interaction with $\mathrm{H}$, using the GST-H [1-292] fusion protein immobilized on glutathioneagarose beads (see also Fig. 5A). GST is used here as a negative control. Input lanes $(1,4,7,10,13)$ show the different Su(H) in vitrotranslated products, as indicated above the lanes. The fraction of each $\mathrm{Su}(\mathrm{H})$ protein retained onto GST-H [1-292] beads is shown in lanes $2,5,8,11$, and 14 , and nonspecific binding of $\mathrm{Su}(\mathrm{H})$ proteins to GST beads is indicated in lanes $3,6,9,12$, and 15 . Between $50 \%$ and $70 \%$ of $\mathrm{Su}(\mathrm{H})[10-594]$ or $[10-525]$ is reproducibly retained onto GST-H [1-293] beads (lanes 2,5$)$, compared with the $0.5-2 \%$ background levels observed with the GST beads alone (lanes 3,6). No specific binding is detectable for the Su(H) [10-457], [10-399], and [10-287] constructs (lanes 7-15). Molecular mass markers are indicated at the left of the 10\% polyacrylamide gel. (Lanes 16-22) $\left[{ }^{35} \mathrm{~S}\right]$ Met-labeled $\mathrm{H}[1-1076]$ was tested for its ability to interact with GST-Su(H) fusion proteins corresponding to progressive aminoterminal deletions (see also $D$ ). For each GST-Su(H) fusion protein, the bound fraction (lanes 17-21) was compared with the input (lane 16) and with the background interaction with GST alone (lane 22). Molecular mass markers are indicated at the left of the $8 \%$ polyacrylamide gel. (C) Deletion mapping of the HID of RBP3. $\left[{ }^{35}\right.$ S|Met-labeled in vitro-translated derivates of RBP3 (as indicated above the lanes) were assayed for their ability to associate with GST-H [1-292] bound to glutathione-agarose beads. Controls were GST alone and GST-p50, which is a fusion protein between GST and the p50 subunit of NF- $\mathrm{B}$, as indicated. Molecular mass markers are indicated at the left of the $10 \%$ or $12 \%$ polyacrylamide gels. Asterisks $\left({ }^{*}\right)$ mark the positions of the in vitro-translated products.

293] protein was not retained on GST-Su(H) [110-594] beads (Fig. 3A, lanes 10-12). Weak $\mathrm{Su}(\mathrm{H}$ ) binding could be detected using the short $\mathrm{H}[212-293]$ in vitro-translated product (Fig. 3A, lanes 13-15), suggesting that this region of the $\mathrm{H}$ protein contributes in part to the interaction with $\mathrm{Su}(\mathrm{H})$.

To map the $\mathrm{H}$ interaction domain within Drosophila $\mathrm{Su}(\mathrm{H})$, we used a bacterially produced GST-H [1-292] fusion protein that contains the domain of interaction with $\mathrm{Su}(\mathrm{H})$ defined above. The nearly full-length in vitrotranslated $\mathrm{Su}(\mathrm{H})[10-594]$ protein was specifically and efficiently retained by the GST-H [1-292] fusion protein, compared with the control GST beads (Fig. 3B, lanes 1-3). The analysis of carboxy-terminal deletion constructs of $\mathrm{Su}(\mathrm{H})$ revealed that $(1) \mathrm{Su}(\mathrm{H})[10-525]$ still interacts with GST-H [1-292] (Fig. 3B, lanes 4-6), indicat- 
ing that the carboxy-terminal sequences that have not been conserved throughout evolution are dispensable for interaction with $\mathrm{H}_{\text {; }}$ and (2) further deletions of conserved sequences abolish the in vitro interaction with GST-H [1-292] [constructs $\mathrm{Su}(\mathrm{H})[10-457], \mathrm{Su}(\mathrm{H})[10-399]$, and $\mathrm{Su}(\mathrm{H})$ [10-287] (Fig. 3B, lanes 7-15; Fig. 5A)]. Aminoterminal deletion constructs were analyzed using a different experimental strategy: GST-Su(H) fusion proteins carrying progressive amino-terminal deletions were tested for their ability to retain the $\mathrm{H}$ [1-1076] in vitrotranslated product. Negative controls include $\mathrm{H}$ binding to GST alone (Fig. 3B, lane 22) and binding of the Drosophila AEF1 nuclear protein on these GST-Su(H) beads (not shown). Deleting the amino-terminal half of the conserved region appears to have no effect on $\mathrm{H}$ binding in vitro [see the GST-Su(H) [288-594] construct in Fig. $3 \mathrm{~B}$, lane 20]. The GST-Su(H) [444-594] deletion construct, which leaves only 84 amino acids from the conserved region upstream of the evolutionary divergent carboxyl-terminal tail shown above to be dispensable for $\mathrm{H}$ binding, still exhibits a weak $\mathrm{H}$-binding activity in this assay (Fig. 3B, lane 21). Similar results were obtained using the $\mathrm{H}$ [1-293] in vitro-translated product (not shown). We conclude that the $\mathrm{H}$ interaction domain (HID) is included within the conserved region of $\mathrm{Su}(\mathrm{H})$, between amino acids 288 and 525 (see Fig. 5A, below).

The genetic interactions observed between $H$ and $\mathrm{Su}(H)$ are thought to unravel a fundamental aspect of $\mathrm{Su}(\mathrm{H})$ function. Because of the very strong conservation of $\mathrm{Su}(\mathrm{H}) / \mathrm{RBP}$ primary structure during evolution, we believe that both proteins share similar biochemical activities. We therefore investigated the ability of the RBP3 isoform to interact with Drosophila $\mathrm{H}$. In vitro-translated $\mathrm{H}$ [1-1076] and $\mathrm{H}$ [1-293] interacted with GSTRBP [1-486] (data not shown), and, conversely, the RBP3 in vitro-translated protein (RBP3 [1-486]) was retained onto the GST-H [1-292] fusion protein bound to glutathione-agarose beads (Fig. 3C, lane 3). This interaction appears specific because no significant signal was detected upon binding onto GST or GST-P50, a fusion protein that consists in the p50 subunit of NF- $\mathrm{kB}$ fused to GST (Fig. 3C, lanes 1,2). A deletion analysis of RBP3 was carried out to independently define the HID. The RBP3 [1-435] and RBP3 [175-486] mutant proteins were still specifically retained onto GST-H [1-292] beads (Fig. 3C, lanes 7-9,13-15). This indicates that sequences upstream of amino acid 175 and downstream of amino acid 435 are dispensable for interaction with $\mathrm{H}$ in this assay. However, the RBP3 [1-329] and RBP3 [1-271] carboxyterminal truncated proteins were unable to interact with $\mathrm{H}$ (Fig. 3C, lanes 10-12, and 4-6, respectively). We then assayed a short internal region (RBP3 [330-438]) for its capacity to interact with GST-H $[1-292]$; as shown in Figure 3C (lanes 16-18), this 108-amino-acid in vitrotranslated product is specifically retained onto GST-H [1-292] beads. Thus, RBP3 can interact in vitro with Drosophila $\mathrm{H}$. Both $\mathrm{Su}(\mathrm{H})$ and RBP3 interact with a similar region of $\mathrm{H}$, located between amino acid positions 1 and 292 (Figs. 3A and 5B; data not shown). Likewise, a similar HID can be defined in both $\mathrm{Su}(\mathrm{H})$ and RBP3 pro- teins (Fig. 5A, below). Note also that the HID partly overlaps the DNA-binding domain (see Fig. 5A, below).

\section{In vivo interaction between $R B P 3$ and $H$ in yeast}

RBP3-H protein interaction was then tested in vivo using the yeast two-hybrid system (Fields and Song 1989; Durfee et al. 1993; Harper et al. 1993). Two series of expression plasmids were constructed: One encodes segments of the RBP3 protein fused to the GAL4 DNAbinding domain [GAL(DB) plasmids in Table 1]; the other encodes the GAL4 activation domain, either alone [plasmid GAL $\mid \mathrm{AD})$ ] or fused to the first 292 amino acids of $\mathrm{H}$ (plasmid GAL(AD)-H [1-292]). Each pair of plasmids was cotransformed into a yeast strain carrying a GAL4 upstream activating sequence (UAS)-lacZ reporter construct integrated into its genome (Harper et al. 1993). RBP3-H interactions would be expected to mediate the formation of a complex between the GAL/DB)RBP3 and GAL $(A D)-H$ [1-292] proteins, resulting in the restoration of transcriptional activity. This would be detected as a blue yeast colony because of induced $\beta$-galactosidase activity. First, the GAL(DB)-RBP3 fusion constructs were not sufficient to induce detectable transcriptional activation of the UAS-lacZ gene when cotransformed with GAL(AD), with the exception of the GAL(DB)-RBP3 [330-438] fusion protein that gave light blue colonies (Table 1). Similarly, the H [1-292] domain fused to the GAL4 transcription activation domain did not induce lac $Z$ reporter gene transcription when cotransformed with the GAL(DB). In contrast, easily detectable lac $Z$ expression was observed when the GAL(DB)-RBP3 [1-486], GAL(DB)-RBP3 [175-486], and GAL(DB)-RBP3 [330-438] constructs were cotransformed with the GAL/AD)-H [1-292] plasmid. As a negative control, lac $Z$ expression was not restored when using GAL(DB)-RBP3 [1-271], in which the HID is deleted. Thus, activation of the $1 a c Z$ reporter gene transcription most likely results from specific protein-protein inter-

Table 1. $R B P 3$ and $H$ interact in vivo in yeast

\begin{tabular}{lcc}
\hline & \multicolumn{2}{c}{$\beta$-Galactosidase activity } \\
\cline { 2 - 3 } Fusion proteins & GAL(AD) & GAL(AD)-H [1-292] \\
\hline GAL(DB) & - & - \\
GAL(DB)-RBP3 & - & ++ \\
GAL(DB)-RBP3 [1-271] & - & - \\
GAL(DB)-RBP3 [175-486] & - & +++ \\
GAL(DB)-RBP3 [330-438] & $-/+$ & ++ \\
\hline
\end{tabular}

Two series of plasmids were constructed, one encoding the GAL(DB) fused to various fragments of RBP3 (amino acid numbering refers to RBP3|, and the other encoding a hybrid of the GAL4 activation domain GAL(AD) fused to the first 292 amino acids of $\mathrm{H}(\mathrm{GAL}(\mathrm{AD})-\mathrm{H}$ [1-292]). The plasmids were introduced into a yeast strain containing the lacZ reporter gene under the control of GAL4 elements. $\beta$-Gal activity was monitored semiquantitatively by the colony lift assay. $(+++)$ Colonies turned blue in $<15 \min _{i}(++)$ in $15-60 \min _{i}(-)$ colonies remained white. 
action in the yeast nucleus between the HID of RBP3 and H [1-292]. These results fully confirm our conclusions based on the in vitro study presented in Figures 3 and 5 .

\section{$H$ inhibits the DNA-binding activity of $\mathrm{Su}(\mathrm{H})$ and $R B P$ proteins}

The antagonistic nature of $H$ and $S u(H)$ activities, together with the direct protein-protein interaction between $\mathrm{H}$ and $\mathrm{Su}(\mathrm{H})$, suggest that $\mathrm{H}$ could possibly control the activity of $\mathrm{Su}(\mathrm{H})$. This could be at the level of DNA binding, subcellular localization, or transcriptional activity on DNA binding of $\mathrm{Su}(\mathrm{H})$. We first examined whether the in vitro-translated $\mathrm{H}$ protein affects the DNA-binding activity of $\mathrm{Su}(\mathrm{H})$ (Fig. 4A, lanes 1-7). Increasing amounts of $\mathrm{H}$, added to a constant amount of $\mathrm{Su}(\mathrm{H})$ proteins and DNA probes (Fig. 4A, lane 3 ; data not shown|, correlates with a progressive reduction in the intensity of the retarded complex. Adding a twofold molar excess of the $\mathrm{H}$ protein, relative to $\mathrm{Su}(\mathrm{H})$, decreases the amount of the retarded complex by about threefold (data not shown). $\mathrm{H}$ alone did not bind to the 2122 nor HES probes (Fig. 4A, lanes 1,11; data not shown), and the formation of new, supershifted complexes was not observed. Thus protein-protein interactions between $\mathrm{H}$ and $\mathrm{Su}(\mathrm{H})$ apparently lead to the formation of complexes that are unable to recognize the $\mathrm{Su}(\mathrm{H})$ target site. The specificity of this inhibitory effect could be demonstrated further using two $\mathrm{Su}(\mathrm{H})$ truncated proteins. $\mathrm{Su}(\mathrm{H})$ [10-525] was shown to both bind DNA (Fig. 2C, lane 3) and interact in vitro with $\mathrm{H}$ (Fig. 3B, lane 5). Consistent with these data, we show here that $\mathrm{H}$ inhibits the DNA binding of $\mathrm{Su}(\mathrm{H})$ [10-525] (Fig. 4A, lanes 4,5). In contrast, $\mathrm{Su}(\mathrm{H})[10-457]$ is known to bind DNA but not $\mathrm{H}$ (Fig. 2C, lane 4; Fig. 3B, lane 8; Fig. 5A, below): Accordingly, $\mathrm{H}$ had no detectable effect on its DNA-binding ability (Fig. $4 \mathrm{~A}$, lanes 6,7$)$. This result confirms that a region between amino acids 457 and 525 in $\mathrm{Su}(\mathrm{H})$ is necessary for interaction with $\mathrm{H}$ but not for DNA binding (Fig. 5A). We then investigated whether Drosophila $\mathrm{H}$ may also inhibit KBF2/RBP-JK DNA-binding activity. As shown in Figure 4A, $\mathrm{H}$ effectively decreases binding of purified KBF2 (Fig. 4A, lanes 8,9), as well as of the in vitro-translated proteins RBP1 (lanes 13,14), RBP3 (lanes 10,12), and RBP4 (data not shown), to the HES probe. A similar inhibitory effect was also observed with recombinant GST-RBP3 fusion protein (Fig. 4B, cf. lanes 11 and 7) or with the endogenous KBF2 activity present in nuclear extracts from several cell lines (human kidney 293T and neuroblastoma NGP, mouse myoblast $\mathrm{C}_{2}$; data not shown). As a negative control we verified that $\mathrm{H}$ does not affect the DNA-binding activity of the p50 subunit of NF- $\kappa B$ (data not shown). Finally, several H-deletion mutants were tested for their capacity to inhibit $\mathrm{Su}(\mathrm{H})$ or RBP3 DNA-binding activity. A similar fivefold molar excess of $\mathrm{H}$ proteins relative to $\mathrm{Su}(\mathrm{H})$ was used for all $\mathrm{H}$-deletion constructs (Fig. 4B, lanes 1-6). The amount of $\mathrm{H}$ proteins compared with bacterially produced GST-RBP3 proteins was kept constant in all lanes (Fig. 4B, lanes 7-11). Full-length $H$ and $H$ [1-710] exhibited strong
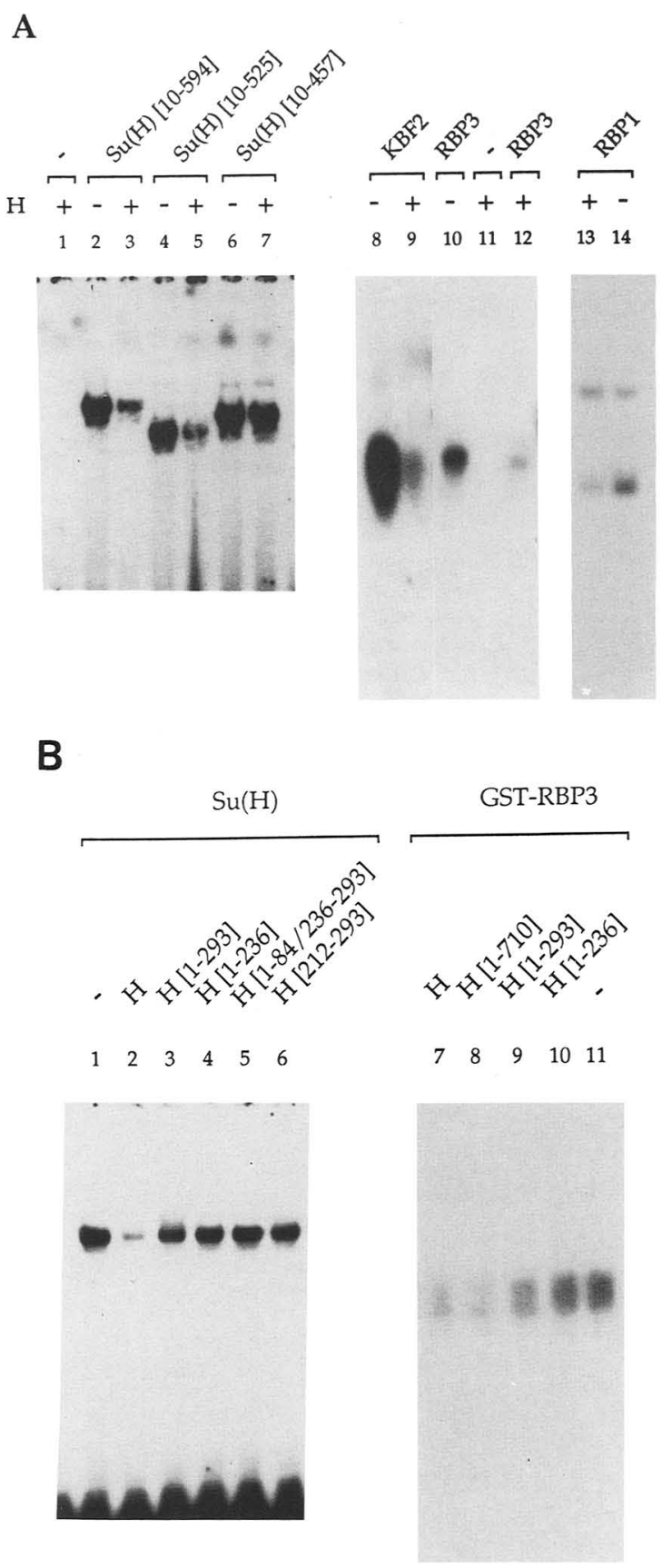

Figure 4. $\mathrm{H}$ inhibits the DNA-binding activity of $\mathrm{Su}(\mathrm{H}), \mathrm{KBF} 2$, and RBP isoforms. (A) A fivefold molar excess of in vitro-translated $H$ (lanes $1,3,5,7,9,11,12,13$ ) or unprogrammed rabbit reticulocyte lysate (lanes $2,4,6,8,10,14)$ was preincubated with in vitro-translated $\mathrm{Su}(\mathrm{H})$ (lanes 2,3), $\mathrm{Su}(\mathrm{H})$ [10-525] (lanes 4,5), $\mathrm{Su}(\mathrm{H})$ [10-457] (lanes 6,7), RBP3 (lanes 10,12), RBP1 (lanes 13,14 ), or purified KBF2 (lanes 8,9) before addition of 2122 (lanes $1-7)$ or HES probe (lanes $8-14$ ) and assayed by gel shift. $(B)$ Deletion mapping of the $\mathrm{H}$ region required to inhibit the binding of $\mathrm{Su}(\mathrm{H})$ to the 2122 probe (lanes $1-6$ ) or of recombinant GST-RBP3 to the HES probe (lanes 7-11). Identical amounts of in vitro-translated $\mathrm{H}$ (lanes 2,7), $\mathrm{H}$ [1-710] (lane 8), $\mathrm{H}$ [1-293] (lanes 3,9), H [1-236] (lanes 4,10), H [1-84/236-293] (lane 5), H [212-293] (lane 6), or unprogrammed lysate (lanes 1,11) were incubated with $\mathrm{Su}(\mathrm{H})$ or GST-RBP3 as indicated, before addition of probes 2122 (lanes 1-6) or HES (lanes 7-11). 
A

Suppressor of Hairless

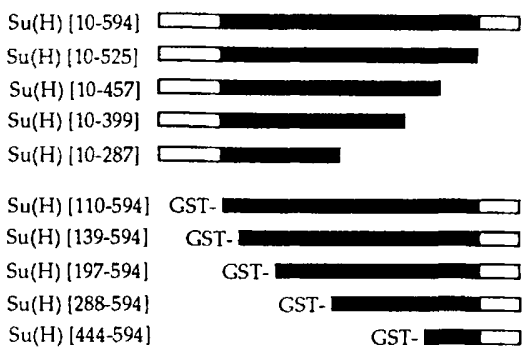

Human RBP3

RBP3 [1-486]
RBP3 [1-435]
RBP3 $[1-329]$
RBP3 [1-271]
RBP3 [175-486]
RBP3 [330-438]
RBP3 [7-486]
RBP3 [98-486]

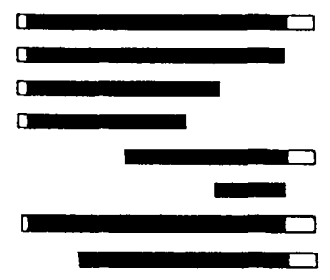

+
+
-
-
-
+
-

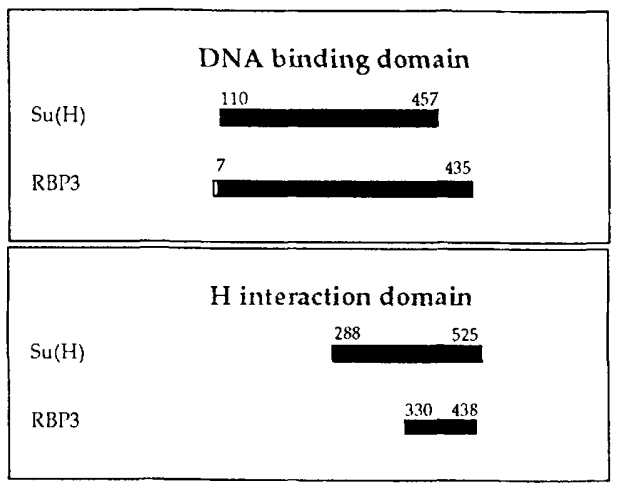

B
Hairless

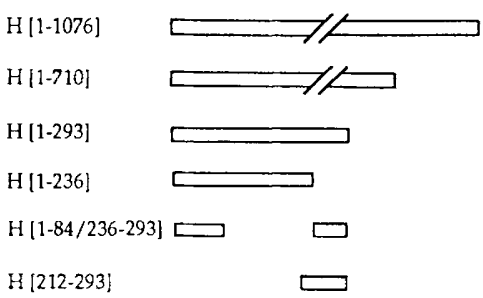

DNA binding

+
+
+
-
+
-
-
-

$\begin{array}{cc}\text { in vitro } & \text { inhibition of } \\ \text { interaction } & \text { DNA binding } \\ \text { with } \mathrm{H} & \text { by } \mathrm{H}\end{array}$

+
+
-
-
-
+
+
+
+
$+/-$
$+$

+ (ns)

$+(n s)$

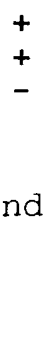

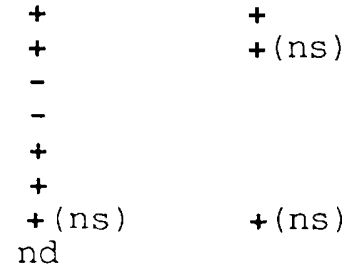

Figure 5. Schematic representation of the functional domains of the $\mathrm{Su}(\mathrm{H}), \mathrm{RBP} 3$, and $\mathrm{H}$ proteins. $(A)$ Deletion mapping of $\mathrm{Su}(\mathrm{H})$ (top) and RBP3 (bottom) DNA-binding domain and HID. $\mathrm{Su}(\mathrm{H})$ and RBP3 are drawn at the same scale and are aligned following their highly conserved region represented as a solid box $[\mathrm{Su}(\mathrm{H})$, amino acids $103-528$; RBP3, amino acids 15-440]. The results of the gel shift experiments of Fig. 2, B and C, are summarized in the column labeled DNA binding $1+$, DNA binding; -, no DNA binding), the results of the in vitro interaction experiments of Fig. 3 in the column labeled in vitro interaction with $\mathrm{H} /+$, interaction with $\mathrm{H}_{;}-$, no detectable interaction; $+/-$, weak interaction; ns, not shown; nd, not determined), the results of gel shift experiments of Fig. 4 in the column labeled inhibition of DNA binding by $\mathrm{H}(+, \mathrm{H}$ inhibits the DNA binding of this protein; $\mathrm{H}$ has no effect on DNA binding). In the central part, the DNA-binding domain and the HID of $\mathrm{Su}(\mathrm{H})$ and $\mathrm{RBP} 3$ are compared. (B) Deletion mapping of the $\mathrm{H}$ protein. The results presented in Figs. 3 and 4 are summarized here as in $A$.
DNA-binding inhibition activity, whereas $\mathrm{H}$ [1-293] gave a weaker inhibitory effect (Fig. 4B lanes 2,3,7-9). The $\mathrm{H}$ [1-236], $\mathrm{H}$ [1-84/236-293], and $\mathrm{H}$ [212-293] mutant proteins had no inhibitory effects upon $\mathrm{Su}(\mathrm{H})$ DNA binding (Fig. 4B, lanes $4-6,10$ ). These results, summarized in Figure $5 B$, are all consistent with the in vitro protein interaction results (Figs. $3 \mathrm{~A}$ and $5 \mathrm{~B}$ ), with the exception of the $\mathrm{H}$ [212-293], which was able to weakly 
interact in vitro with $\mathrm{GST}-\mathrm{Su}(\mathrm{H})[110-594]$ but did not inhibit $\mathrm{Su}(\mathrm{H})$ DNA-binding activity or supershift the retarded complex.

\section{$H$ inhibits $S u(H)$-dependent transcriptional activation in transfected $S 2$ cells}

The importance for transcription regulation of the inhibition by $\mathrm{H}$ of the $\mathrm{Su}(\mathrm{H})$ DNA-binding activity was examined in cotransfection experiments using the Drosophila cell line S2 (Fig. 6). Two direct repeats of the 2122 DNA-binding sites were introduced upstream of the minimal Adh promoter [ $-86,+53]$ (England et al. 1990) driving CAT gene expression $\left[(2122)_{2} \mathrm{Adh}-86 \mathrm{CAT}\right]$. CAT activity was measured following cotransfection of the above with expression plasmids producing the $\mathrm{Su}(\mathrm{H})$ and/or $\mathrm{H}$ gene products under the control of the actin $5 \mathrm{C}$ promoter.

First, although no effect was observed using the Adh86 CAT reporter plasmid alone, CAT expression from the (2122) $)_{2}$ Adh-86 CAT construct was increased upon cotransfection with $\mathrm{Su}(\mathrm{H})$. Average stimulation was found to be 7.4-fold, indicating that $\mathrm{Su}(\mathrm{H})$ acts as a transcriptional activator in this assay. Second, cotransfection of the $\mathrm{Su}(\mathrm{H})$ and $\mathrm{H}$ expression vectors resulted in a dosedependent reduction of the stimulated CAT expression. The $\mathrm{Su}(\mathrm{H})$-dependent stimulation was 2.9 -fold with a

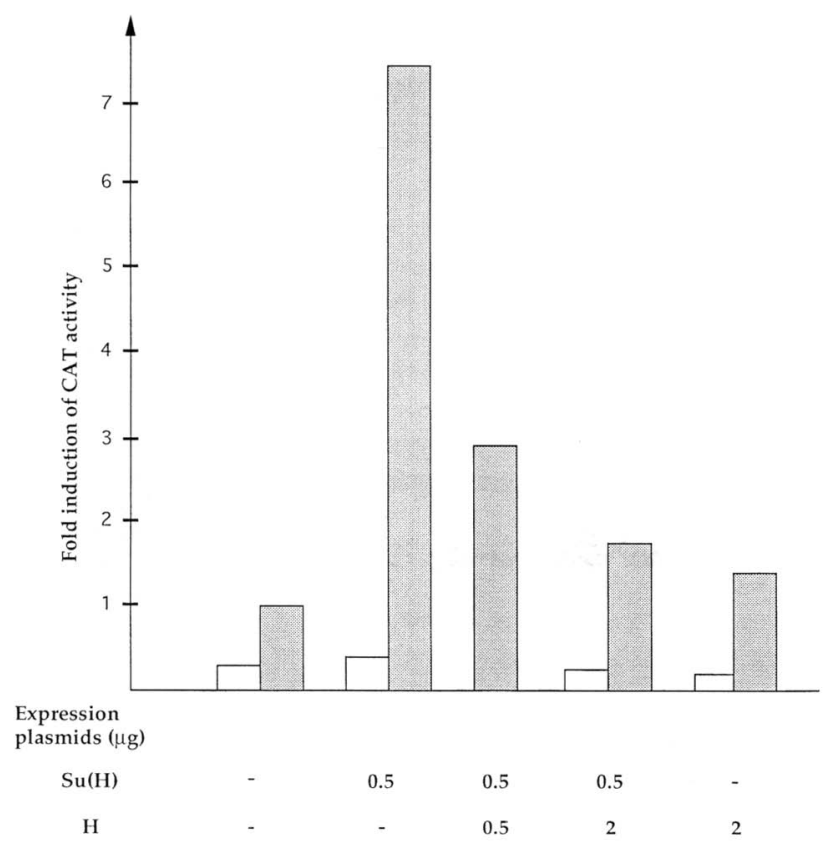

Figure 6. Transcriptional activities of $\mathrm{Su}(\mathrm{H})$ and $\mathrm{H}$ in Drosophila S2 cells. CAT assays of S2 cell extracts following transfection with $2 \mu \mathrm{g}$ of the reporter genes Adh-86 CAT (open bars) or (2122) ${ }_{2}$ Adh-86 CAT (shaded bars) along with variable amounts of the $\mathrm{Su}(\mathrm{H})$ and/or $\mathrm{H}$ expression vectors as indicated. Histograms correspond to the average of at least three independent experiments. Each activity is compared with that of $(2122)_{2} \mathrm{ADH}-86$ taken as 1 . Values corresponding to each bar are as follows: $0.3 ; 1 ; 0.4 ; 7.4 ; 2.9 ; 0.25 ; 1.8 ; 0.2 ; 1.4$.
$\mathrm{H} / \mathrm{Su}(\mathrm{H})$ ratio of $1: 1$, and 1.8 -fold with a $4: 1$ ratio. As a control, $\mathrm{H}$ did not, on its own, affect the level of expression of the two reporter genes used. These results indicate that $\mathrm{H}$ may inhibit in vivo the transcriptional activation of a synthetic promoter mediated by $\mathrm{Su}(\mathrm{H})$.

\section{Discussion}

We report here the cloning of a cDNA encoding the KBF2 protein. Peptide and cDNA sequencing revealed that $K B F 2$ is identical to $R B P-/ \kappa$ (Matsunami et al. 1989; Amakawa et al. 1993). The genomic organization of the human $R B P-J \kappa$ gene has been reported (Amakawa et al. 1993). Three different splicing products, RBP1, RBP2, and RBP3 (according to the nomenclature proposed in this paper|, have been described by Amakawa et al. (1993). We describe here a fourth isoform, RBP4, that contains part of exon N1 linked to exon 2. A fifth protein that corresponds to the previously described mouse splicing product RBP2N (Kawaichi et al. 1992) was reported recently (Dou et al. 1994). It is possible that other potential splicing products may exist. The purified KBF2 activity may thus correspond to a single splicing product or a combination of specific RBP splicing products. The DNA-binding domain of RBP maps to a large, highly conserved region common to all isoforms [from amino acid 7 to 435 in RBP3, and from 110 to 457 in $\mathrm{Su}(\mathrm{H})]$. The possible functional diversity associated with these various RBP isoforms remains to be investigated. Similarly, although the $R B P-/ \kappa$ gene products are expressed in many different cell types (Hamaguchi et al. 1992; data not shown), the detailed expression pattern of each isoform has not been described and awaits the use of isoform-specific probes.

\section{Direct protein-protein interaction with Drosophila $H$ prevents $\mathrm{Su}(\mathrm{H}) / \mathrm{RBP} 3$ binding to $D N A$}

Further insights into the possible regulation of RBP activity were gained from studies of $S u(H)$ function in fly development. $\mathrm{Su}(H)$, together with $H$, controls at least two alternative cell fate decisions during peripheral nervous system (PNS) formation of the adult fly (Bang et al. 1991; Bang and Posakony 1992; Schweisguth and Posakony 1992, 1994). We show here that $\mathrm{Su}(\mathrm{H})$ binds the consensus-binding site defined for the mouse RBP protein and acts upon transfection as a transcriptional activator of an artificial promoter carrying two copies of this sequence. These two assays for $\mathrm{Su}(\mathrm{H})$ function allowed us to investigate the molecular basis of the antagonistic activity of the $\mathrm{H}$ protein, for which no biochemical activity is known so far. First, $\mathrm{H}$ acts as a repressor by decreasing in a dose-dependent manner the transcriptional activation mediated by $\mathrm{Su}(\mathrm{H})$ in transfected cells. We show further that $\mathrm{H}$ specifically prevents $\mathrm{Su}\langle\mathrm{H}\rangle$ binding to its target site in vitro and that $\mathrm{H}$ interacts directly with $\mathrm{Su}(\mathrm{H})$ in vitro. The ability of $\mathrm{H}$ to inhibit $\mathrm{Su}(\mathrm{H})$ DNA binding extends to its vertebrate cognates, RBP1, $\mathrm{RBP} 3$, and RBP4, as well as to purified KBF2. Likewise, $\mathrm{H}$ and RBP3 were shown to interact in vivo using the yeast 
two-hybrid system and in vitro by direct protein-protein interactions. The functional domain required for interaction with $\mathrm{H}$ (HID) lies within the region highly conserved between $\mathrm{Su}(\mathrm{H})$ and RBP-Jк. The HID displays a high percentage of prolines $(10 \%)$ and hydrophobic amino acids $228 \%$ for RBP3 [330-438] and $26 \%$ for the corresponding region of $\mathrm{Su}(\mathrm{H})$ [419-527]). We note that the $\mathrm{H}$ domain required for the interaction with $\mathrm{Su}(\mathrm{H})$ also includes a potential $\alpha$-helix [223-247] with hydrophobic residues on one side of the helix. The role of these hydrophobic residues in the formation of $\mathrm{H}-\mathrm{Su}(\mathrm{H}) \mathrm{com}$ plexes remains to be investigated. The PRD repeat located at the carboxy-terminal end of the $\mathrm{H}$ protein, which may regulate protein-protein interactions (Janknecht et al. 1991), plays no apparent role in the $\mathrm{H}-\mathrm{Su}(\mathrm{H})$ interaction.

The mechanism by which $H$ prevents $S u(H) / R B P$ DNA binding is at unclear present. Considering that the HID partly overlaps the $\mathrm{Su}(\mathrm{H}) / \mathrm{RBP} 3$ DNA-binding domain, it is possible that $\mathrm{H}$ partly masks the DNA interaction surface of $\mathrm{Su}(\mathrm{H})$ and $\mathrm{RBP} . \mathrm{H}$ and $\mathrm{Su}(\mathrm{H}) / \mathrm{RBP}$ would then form stable complexes unable to bind DNA. This hypothesis is reminiscent of the mechanism by which calreticulin prevents the glucocorticoid receptor from binding to its DNA response element (Burns et al. 1994; Dedhar et al. 1994) or IP1 inhibits AP1 DNA binding (Auwerx and Sassone-Corsi 1991). An alternative mechanism that cannot be formally excluded is one in which the $\mathrm{H}-\mathrm{Su}(\mathrm{H}) / \mathrm{RBP}$ complex could still bind DNA but with an altered specificity.

\section{Could the formation of $\mathrm{H}-\mathrm{Su}(\mathrm{H})$ heteromeric complexes account for the antagonistic genetical interactions observed between $\mathrm{H}$ and $\mathrm{Su}(\mathrm{H})$ ?}

The results described in this paper would fully support a model in which $H$ acts as a negative regulator of $\mathrm{Su}(H)$ activity. However, the dose-sensitive genetic interactions associated with partial loss of function in these two genes initially led Ashburner (1982) to propose that $\mathrm{Su}(H)$ acts as a negative regulator of $H$ function. This conclusion stems from the observation that a reduction in $\mathrm{Su}(H)$ gene dosage suppresses the partial $H$ loss-offunction phenotype, whereas an increase in gene dosage enhances it (Ashburner 1982). However, as first pointed out by Locke et al. (1988), these dose-dependent effects could also be explained by the formation of multiprotein complexes involving the $\mathrm{Su}(\mathrm{H})$ protein. We thus propose that $\mathrm{Su}(\mathrm{H})$ acts on DNA binding to favor the adoption of an epithelial, that is, epidermal and socket-producing, cell fate and that $\mathrm{H}$ inhibits its DNA-binding activity to promote a subepithelial, that is, neuronal and shaft-secreting, cell fate. This proposal is entirely consistent with a role for $H$ in protecting the future SOP cell from residual negative signaling that would be mediated by $\mathrm{Su}(H)$ (Bang and Posakony 1992). The observation that the neurogenic $\mathrm{Su}(\mathrm{H})$ null phenotype is partially suppressed in $\mathrm{Su}(H){ }_{i} H$ double mutant larvae (Schweisguth and Posakony 1994) may also suggest that $H$ acts inde- pendently of $S u(H)$ to negatively regulate additional neurogenic activities. Thus, it is possible that $\mathrm{H}$, when not associated with $\mathrm{Su}(\mathrm{H})$, may still participate in other regulatory interactions. We propose that direct protein-protein interactions between $\mathrm{H}$ and $\mathrm{Su}(\mathrm{H})$ control both the activity of $\mathrm{Su}(\mathrm{H})$ and the amount of $\mathrm{H}$ protein unbound to $\mathrm{Su}(\mathrm{H})$. The dominant loss of $H$ function phenotype predicts that $\mathrm{H}$ is present in limiting amount. A threefold increase in $S u(H)$ gene dosage results in an adult phenotype very similar to the dominant $H$ phenotype observed in $H$ heterozygote flies (Schweisguth and Posakony 1994; data not shown). Although the subcellular distribution of the $\mathrm{H}$ protein is not yet known, the nuclear localization of both $\mathrm{Su}(\mathrm{H})(\mathrm{F}$. Schweisguth, M. Lecourtois, and J.W. Posakony, unpubl.) and RBP (Hamaguchi et al. 1992) suggests that the $\mathrm{H}-\mathrm{Su}(\mathrm{H})$ complex probably forms in the nucleus.

\section{Functional conservation between $\mathrm{Su}(\mathrm{H})$ and $\mathrm{RBP}-\mathrm{\kappa}$}

Our results suggest a possible interpretation for the remarkable degree of structural similarity between $\mathrm{Su}(\mathrm{H})$ and RBP. First, these proteins have a large DNA-binding domain. Second, the highly conserved sequences that are not required for DNA binding appear involved in protein-protein interactions. Considering that regulation by $H$ is a fundamental aspect of $S u(H)$ activity in flies and that the human RBP proteins interact with Drosophila $\mathrm{H}$ in a manner identical to $\mathrm{Su}(\mathrm{H})$, we propose that a human $\mathrm{H}$ homolog should exist that has the same ability to interact with the RBP proteins. Experiments are in progress to isolate this human homolog of $\mathrm{H}$. This study also suggests another level of functional conservation between $\mathrm{Su}(\mathrm{H})$ and RBP. Genes from the $E$ (spl) complex are thought to act at the last step in a genetic cascade of gene activities restricting neural fate and to be the genetic target of the $H$ gene activity (de la Concha et al. 1988). Consistent with this proposition, the promoter of the $m 8$ gene of the $E(s p l)$ complex contains a potential binding site for $\mathrm{Su}(\mathrm{H})$ (Tun et al. 1994; M. Lecourtois and F. Schweisguth, unpubl.). We further report here that the promoter of the HES1 gene, a mammalian homolog of the $E$ (spl) genes, also contains a strong RBP-binding site. This raises the exciting possibility that not only the specificity of DNA binding and the negative regulation by $\mathrm{H}$, but also their direct downstream target genes have been conserved throughout evolution. Whether RBP-J $\kappa$ may also act as $S u(H)$ in the Notch-mediated signaling pathway during mammalian development remains to be determined.

\section{Materials and methods}

Purification and cloning of KBF2

KBF2 was purified from 250 grams of HeLa cells. Its activity was followed by bandshift assay as described in Israël et al. (1989). Nuclear extract preparation, ammonium sulfate precipitation, and hydroxylapatite chromatography have been described in $\mathrm{Ki}$ eran et al. (1990). The fraction eluted from the hydroxylapatite 
column, which contains both KBF1 and KBF2, was dialyzed against a buffer containing $0.1 \mathrm{M} \mathrm{NaCl}$ and then loaded onto a DNA affinity column containing the $\mathrm{H}-2 \mathrm{~K}^{\mathrm{b}} \kappa \mathrm{B}$ site in the presence of poly[d(I-C)] (Kieran et al. 1990). This step allowed separation of KBF1, retained onto the affinity column, from KBF2 that does not bind to the $\mathrm{H}-2 \mathrm{~K}^{\mathrm{b}} \mathrm{\kappa B}$ site under the conditions used. The flowthrough was subsequently loaded onto a heparinagarose column. $\mathrm{KBF} 2$ activity was eluted at $0.3 \mathrm{M} \mathrm{NaCl}$, dialyzed, and loaded onto a sulfopropyl ion-exchange column. Active fractions eluting at $0.6 \mathrm{M} \mathrm{NaCl}$ were pooled and dialyzed against a buffer containing $50 \mathrm{~mm} \mathrm{NaCl}$. A second DNA affinity column containing the $\beta 2 \mathrm{~m}$ site (Israël et al. 1989) was then used. Most of the KBF2 activity bound to this column, and the $\mathrm{KBF} 2$ protein was eluted at $0.2 \mathrm{M} \mathrm{NaCl}$. The active fraction was dialyzed and loaded once again onto the $\beta 2 \mathrm{~m}$ affinity column. SDS gel analysis detected a single $58-\mathrm{kD}$ protein. This $58-\mathrm{kD}$ protein could be specifically cross-linked by UV irradiation to the $\beta 2 \mathrm{~m}$ oligonucleotide (Israël et al. 1989). The purified protein fraction $(15 \mu \mathrm{g})$ was dialyzed against $10 \mathrm{~mm}$ ammonium acetate (pH 6.0), $0.02 \%$ SDS, and lyophilized. Tryptic peptides were prepared. Three of the seven purified peptides (peptides 8,9 , and 14) were sequenced as described in Kieran et al. (1990).

The sequences of the peptides are peptide 8, QTALLDADDPVSQLH; peptide 9, QPVQVPVTLVR; and peptide 14, V?FGDVEAET/DMY. Degenerated oligonucleotides deduced from the sequence of peptides 8 and 14 (primer $8^{+}$, CAGACAGCCCTGCTGAATGCTGATGACCCTGTCTCCCAGCTGCA; and primer $14^{-}$, AAACCICTACAICTCCGICT) were synthetized and used as primers in polymerase chain reactions (PCRs), using a $\lambda \mathrm{gt} 10$ library derived from the human T47D carcinoma as template (gift of H. Loosfelt, Kremlin Bicêtre, France). PCR conditions were as follows: $1 \mathrm{~min}$ at $94^{\circ} \mathrm{C}, 1 \mathrm{~min}$ at $50^{\circ} \mathrm{C}$, and $1 \mathrm{~min}$ at $72^{\circ} \mathrm{C}$, for 30 cycles. The DNA fragment obtained after amplification was cloned into $\mathrm{pBluescript}$ (Stratagene). This fragment was used to screen $2 \times 10^{6}$ plaques from the same $\lambda \mathrm{gt} 10 \mathrm{cDNA}$ library. A 1.3-kb cDNA was isolated and subcloned into pBluescript. Sequencing was done on both strands using the dideoxy technique. The sequence encoded by the largest open reading frame contained peptides 8,9 , and 14 and corresponded to amino acids $16-449$ of the aPCR3 splice product of RBP-Jk (Amakawa et al. 1993).

\section{Isolation of the isoform-specific RBP $c D N A s$}

Three oligonucleotides-5'-cgtggatccATGGACCACACGGAGGGCTTG-3', 5' -cgtggatccATGCGCAGTGCCGCTCGCGGG3 ', and 5'-cgtggatccGCATGGATTAAAAGGAAA-3' - that correspond to the $5^{\prime}$ ends of the human RBP1, RBP2, and RBP3 isoforms, respectively (Amakawa et al. 1993), were used in PCR experiments in combination with a common oligonucleotide, 5 '-cgcggatccTTAGGATACCACTGTTGGTGTAGA, whose sequence is derived from exon 11. BamHI sites were introduced at the $5^{\prime}$ end of the primers. PCR experiments were carried out using either the same human T47D carcinoma library as above or a human lymphocyte cDNA library (gift of S. Elledge, Howard Hughes Medical Institute, Houston, TX). In both cases, the same two amplification products were obtained under standard conditions. Following subcloning at the BamHI site of pT7 $\beta$ link (Pollock and Treisman 1991) and sequencing analysis, we confirmed the presence of full-length cDNA clones encoding RBP1 and RBP3 in these libraries.

In a further attempt to isolate a RBP2 cDNA, poly $(A)^{+}$RNAs from HeLa, Daudi, K562, and T47D cell lines were subjected to reverse transcription using an oligo(dT) primer with the MuLV transcriptase, followed by PCR amplification. In all cases, a 1.5$\mathrm{kb}$ fragment was obtained, although the expected size for the
RBP2 cDNA is $1.6 \mathrm{~kb}$. The HeLa RT-PCR product was subcloned and sequenced: It corresponds to RBP4 (see Fig. 1).

\section{Synthesis of in vitro-translated products and bandshift assays}

In vitro-translated proteins were all synthesized in a reticulocyte lysate-coupled transcription/translation system (Promega), from cDNA fragments inserted into the pT7 $\beta$ link vector. The cDNA fragment encoding the first 293 amino acids of $\mathrm{H}$ was subcloned following PCR amplification, using a composite fulllength cDNA clone as template (plasmid $\mathrm{KH}$, a gift from A. Preiss, Biozentrum, Basel, Switzerland) (Maier et al. 1993). The full-length $\mathrm{H}$ was obtained by inserting an EcoRI fragment purified from plasmid $\mathrm{KH}$ into the unique EcoRI site of pT7 $\beta$ linkH [1-293]. The amino-terminal deletion mutants RBP3 [175-486], RBP3 [7-486], RBP3 [98-486], and RBP3 [1-271] were obtained by PCR amplification from a template containing the fulllength RBP3 cDNA. The carboxy-terminal deletion mutants RBP3 [1-435], RBP3 [1-329], and H [1-710] were obtained by digestion with restriction enzymes $S a c I, A p a I$, and $X h o I$, respectively, of the corresponding pT7 $\beta$ link constructs. The carboxyterminal deletion mutants $\mathrm{Su}\langle\mathrm{H})[10-525], \mathrm{Su}(\mathrm{H})[10-457], \mathrm{Su}(\mathrm{H})$ $[10-399]$, and $\mathrm{Su}(\mathrm{H})[10-287]$ were obtained from internal deletions of the pT7ßlink $\mathrm{Su}(\mathrm{H})$ [10-594] construct, using the restriction enzymes EagI-Xbal, PstI, NarI-SmaI, and HincllSmaI, respectively. The following $\mathrm{H}$ constructs- $\mathrm{H}$ [1-236], $\mathrm{H}$ [212-293], and $H$ [1-84/236-293]-were generated by internal deletions of the pT7ßlink H [1-293], using the DraI-EcoRI, Ncol-HindIII, and NotI-DraI restriction enzymes.

Bandshift assays were performed as described in Israël et al. (1989) and Antoniewski et al. (1994). The following doublestranded oligonucleotides were used as probes or competitor:

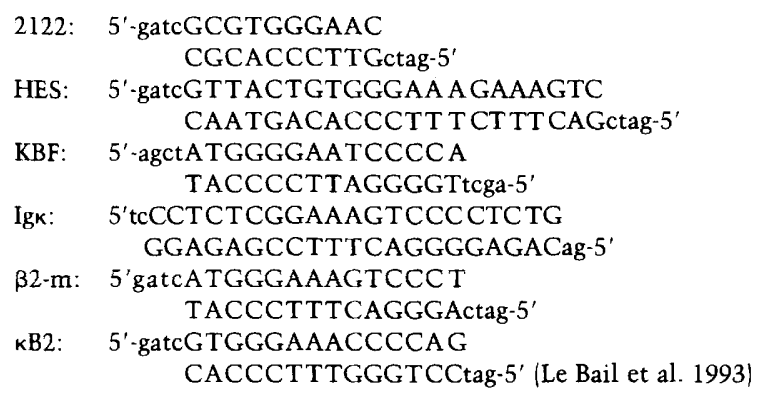

\section{GST fusion proteins and interaction assays}

For GST-RBP3 protein expression in E. coli, a restriction fragment from pT7 $\beta$ link RBP3 construct was subcloned into the pGEX-KT vector as a fusion with GST (Smith and Johnson 1988; Hakes and Dixon 1992). The amino-terminal deletion derivatives of $\mathrm{Su}(\mathrm{H})$ were obtained by subcloning the NcoI-NdeI, XmnI-NdeI, ScaI-NdeI, HincII-NdeI, and MscI-NdeI cDNA fragments purified from KS12 (Schweisguth and Posakony 1992) into the filled-in BamHI site of the pGEX-KG vector (Hakes and Dixon 1992).

The in vitro-translated proteins $(3 \mu \mathrm{l})$ were mixed with glutathione-agarose beads $(10 \mu \mathrm{l})$ coated with GST protein and preadsorbed for $1 \mathrm{hr}$ at $4^{\circ} \mathrm{C}$ in buffer A $/ 40 \mathrm{mM}$ HEPES at $\mathrm{pH} 7.5$, $5 \mathrm{~mm} \mathrm{MgCl}_{2}, 0.2 \mathrm{~mm}$ EDTA, $1 \mathrm{~mm}$ DTT, 0.5\% NP-40, $100 \mathrm{~mm}$ $\mathrm{KCl}$. The supernatant was incubated with glutathione-agarose beads carrying either GST or GST fusion proteins (RBP3, $\mathrm{Su}(\mathrm{H})$, or $\mathrm{H}$ [1-293]) for $1 \mathrm{hr}$ at $4^{\circ} \mathrm{C}$. The beads were washed extensively with buffer A, then with buffer A containing $200 \mathrm{~mm} \mathrm{KCl}$. Associated proteins were eluted by boiling in Laemmli buffer and subjected to SDS-PAGE analysis, followed by fluorography. 


\section{Yeast two-hybrid system}

Y190 strain (Harper et al. 1993) contains a GAL-lacZ reporter integrated into the genome. Its genotype is $\mid M A T a$, leu2-3,112,

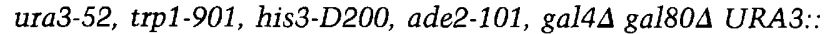
GAL-lacZ, LYS::GAL-HIS3, cyh ${ }^{T}$ ). The pAS1-CYH2-derived plasmids contain the first 147 amino acids of GAL4, which correspond to its DNA-binding domain [GAL(DB)] fused to various fragments of RBP3, obtained by NcoI and XhoI digestion of the pT7ßlink-derived vectors and insertion at the NcoI and SalI sites of pAS1-CYH2. The GAL(AD)-H [1-292] encodes the activation domain of GAL4 [plasmid pACTII (Durfee et al. 1993)] fused to the amino-terminal 292 amino acids of $\mathrm{H}$. The pT7ßlink-H plasmid was digested by $\mathrm{XbaI}$, filled-in by the Klenow enzyme, and redigested by $N$ coI. The appropriate fragment was inserted into pACTII vector digested by NcoI and SmaI.

Y190 was transformed by the pACTII- and PAS1-derived plasmids using the lithium acetate method (Gietz et al. 1992). The transformants were selected on Ura ${ }^{-} \mathrm{Leu}^{-} \mathrm{Trp}^{-}$glucose plates and tested for $\beta$-galactosidase activity using a filter-lift assay (Breeden and Nasmyth 1985). Colonies were transferred onto nitrocellulose filters, permeabilized by freezing in liquid nitrogen, and thawed at room temperature. Filters were then overlaid on Whatman $3 \mathrm{MM}$ paper saturated with an X-gal solution (Breeden and Nasmyth 1985) and incubated at $30^{\circ} \mathrm{C}$. The time required for color development ranged from $10 \mathrm{~min}$ to $2 \mathrm{hr}$.

\section{Cell transfections and CAT assays}

Drosophila Schneider S2 cells were maintained at $25^{\circ} \mathrm{C}$ in Schneider medium (GIBCO) supplemented with $5 \%$ fetal calf serum and $50 \mu \mathrm{g} / \mathrm{ml}$ of penicillin and streptomycin. Cells were transfected using the calcium phosphate coprecipitation technique, at $50 \%$ confluence in 5 -cm plates. Two micrograms of reporter plasmid, different amounts of expression vectors as described in Figure 5, and empty pPac2 expression vector as a carrier, up to a total of $5 \mu \mathrm{g}$, were used for each plate. Transfection efficiency was evaluated by cotransfecting $100 \mathrm{ng}$ of $h s p 82$ lacZ (Dorsett et al. 1989). The (XhoI-XbaI) Su(H) and (KpnI$X b a I \mid H$ cDNA fragments were subcloned between the XhoI or $K p n I$, and $X b a I$ sites, respectively, of the expression vector plasmid pPac2 (a gift of L. Ruel and M. Bourouis, Laboratoire de Génétique Moleculaire des Eucaryotes, Strasbourg, France). A direct repeat of the 2122 oligonucleotide was inserted at the BamHI site upstream of the minimal Adh $[-86,+53]$ promoter to create $(2122)_{2}$ Adh-86 CAT (England et al. 1990). Twenty-four hours after transfection, cells were harvested and lysed in $60 \mathrm{ml}$ of buffer containing $25 \mathrm{mM}$ Tris-phosphate $(\mathrm{pH} 7.81,8 \mathrm{mM}$ $\mathrm{MgCl}_{2}, 1 \mathrm{mM} \mathrm{DTT}, 1 \%$ Triton X-100, and 15\% glycerol. An appropriate amount of extract was incubated in a final volume of $50 \mu \mathrm{l}$ of Tris $(250 \mathrm{~mm}$ at $\mathrm{pH} 7.5)$ for $10 \mathrm{~min}$ at $70^{\circ} \mathrm{C}$, and added directly to $200 \mu \mathrm{l}$ of the reaction mixture $[1.25 \mathrm{~mm}$ chloramphenicol, $\mathrm{O} .5 \mu \mathrm{Ci}$ of ${ }^{3} \mathrm{H}$-labeled acetyl $\mathrm{CoA}(3.6 \mathrm{Ci} / \mathrm{mm}), 125$ $\mathrm{mm}$ Tris at $\mathrm{pH} \mathrm{7.5),} \mathrm{and} 3 \mathrm{ml}$ of Econofluor 2 (NEN DuPont). The linearity of the reaction was verified by counting samples at regular intervals.

\section{Acknowledgments}

We are grateful to L. Ruel, M. Bourouis, J.W. Posakony, A. Preiss, $\mathrm{H}$. Loosfelt, and S. Elledge for gifts of different plasmid constructions and cDNA libraries. We thank J.C. Epinat, O. Le Bail, and M.L. Mackichan for helpful discussions and G. Almouzni, A. Vincent, L. Tora, and S. Whiteside for critical reading of the manuscript. F.S. thanks J.-A. Lepesant for encouragement and support. The present work was supported by grants from CNRS,
INSERM, Association pour la Recherche contre le Cancer, and Ligue Nationale contre le Cancer.

The publication costs of this article were defrayed in part by payment of page charges. This article must therefore be hereby marked "advertisement" in accordance with 18 USC section 1734 solely to indicate this fact.

\section{References}

Akazawa, C., Y. Sasai, S. Nakanishi, and R. Kageyama. 1992. Molecular characterization of a rat negative regulator with a basic helix-loop-helix structure predominantly expressed in the developing nervous system. I. Biol. Chem. 267: 2187921885.

Amakawa, R., W. Jing, K. Ozawa, N. Matsunami, Y. Hamaguchi, F. Matsuda, M. Kawaichi, and T. Honjo. 1993. Human Jk recombination signal binding protein gene (IGKJRB): Comparison with its mouse homologue. Genomics 17: 306-315.

Antoniewski, C., M. Laval, A. Dahan, and J.A. Lepesant. 1994. The Fbp1 enhancer is a target of EcR/USP. Mol. Cell. Biol. 14: $4465-4474$.

Ashburner, M. 1982. The genetics of a small autosomal region of Drosophila melanogaster containing the structural gene for alcohol dehydrogenase. III. Hypomorphic and hypermorphic mutations affecting the expression of Hairless. Genetics 101: 447-459.

Auwerx, J. and C.P. Sassone-Corsi. 1991. IP-1: A dominant inhibitor of Fos/Jun whose activity is modulated by phosphorylation. Cell 64: 983-993.

Bang, A.G. and J.W. Posakony. 1992. The Drosophila gene Hairless encodes a novel basic protein that controls alternative cell fates in adult sensory organ development. Genes \& Dev. 6: $1752-1769$.

Bang, A.G., V. Hartenstein, and J.W. Posakony. 1991. Hairless is required for the development of adult sensory organ precursor cells in Drosophila. Development 111: 89-104.

Breeden, L. and K. Nasmyth. 1985. Regulation of the yeast HO gene. Cold Spring Harbor Symp. Quant. Biol. 50: 643-650.

Burns, K., B. Duggan, E.A. Atkinson, K.S. Famulski, M. Nemer, R.C. Bleackley, and M. Michalak. 1994. Modulation of gene expression by calreticulin binding to the glucocorticoid receptor. Nature 367: 476-480.

Caudy, M., H. Vässin, M. Brand, R. Tuma, L.Y. Jan, and J.N. Jan. 1988. daughterless, a Drosophila gene essential for both neurogenesis and sex-determination has sequence similarities to myc and the achaete-scute complex. Cell 55: 1061-1067.

de la Concha, A., U. Dietrich, D. Weigel, and J.A. CamposOrtega. 1988. Functional interactions of neurogenic genes of Drosophila melanogaster. Genetics 118: 499-508.

Dedhar, S., P.S. Rennie, M. Shago, C.Y. Hagesteijn, H. Yang, J. Filmus, R.G. Hawley, N. Bruchovsky, H. Cheng, R.J. Matusik, and et al. 1994. Inhibition of nuclear hormone receptor activity by calreticulin. Nature 367: 480-483.

Dorsett, D., G.A. Viglianti, B.J. Retlege, and M. Meselson. 1989. Alteration of $h s p 82$ gene expression by the gypsy transposon and suppressor genes in Drosophila melanogaster. Genes \& Dev. 3: 454-458.

Dou, S., X. Zeng, P. Cortes, H. Erdjument-Bromage, P. Tempst, T. Honjo, and L.D. Vales. 1994. The recombination signal sequence-binding protein RBP-2N functions as a transcriptional repressor. Mol. Cell. Biol. 14: 3310-3319.

Durfee, T., K. Becherer, P.L. Chen, S.H. Yeh, Y. Yang, A.E. Kilburn, W.H. Lee, and S.J. Elledge. 1993. The retinoblastoma protein associates with the protein phosphatase type 1 catalytic subunit. Genes \& Dev. 7: 555-569. 
England, B.P., U. Heberlein, and R. Tiian. 1990. Purified Drosophila transcription factor, Adh distal factor-1 (Adf-1), binds to sites in several Drosophila promoters and activates transcription. J. Biol. Chem. 265: 5086-5094.

Falb, D. and T. Maniatis. 1992. Drosophila transcriptional repressor protein that binds specifically to negative control elements in fat body enhancers. Mol. Cell. Biol. 12: 40934103.

Fields, S. and O. Song. 1989. A novel genetic system to detect protein-protein interactions. Nature 340: 245-246.

Furukawa, T., M. Kawaichi, N. Matsunami, H. Ryo, Y. Nishida, and T. Honjo. 1991. The Drosophila RBP-Jk gene encodes the binding protein for the immunoglobulin $\mathrm{J} \kappa$ recombination signal sequence. J. Biol. Chem. 266: 23334-23340.

Ghysen, A. and C. Dambly-Chaudière. 1989. Genesis of the Drosophila peripheral nervous system. Trends Genet. 5: 251-255.

Gietz, D., A. St. Jean, R.A. Woods, and R.H. Schiestl. 1992. Improved method for high efficiency transformation of intact yeast cells. Nucleic Acids Res. 20: 1425.

Hakes, D.J. and J.E. Dixon. 1992. New vectors for high level expression of recombinant proteins in bacteria. Anal. Biochem. 202: 293-298.

Hamaguchi, Y., N. Matsunami, Y. Yamamoto, and T. Honjo. 1989. Purification and characterization of a protein that binds to the recombination signal sequence of the immunoglobulin Jk segment. Nucleic Acids Res. 17: 9015-9026.

Hamaguchi, Y., Y. Yamamoto, H. Iwanari, S. Maruyama, T. Furukawa, N. Matsunami, and T. Honjo. 1992. Biochemical and immunological characterization of the DNA binding protein (RBP-JK) to mouse $\mathrm{J}_{\kappa}$ recombination signal sequence. J. Biochem. 112: 314-320.

Harper, J.W., G.R. Adami, N. Wei, K. Keyomarsi, and S.J. Elledge. 1993. The p21 Cdk-interacting protein Cipl is a potent inhibitor of G1 cyclin-dependent kinases. Cell 75: 805-816.

Ishibashi, M., K. Moriyoshi, Y. Sasai, K. Shiota, S. Nakanishi, and R. Kageyama. 1994. Persistent expression of helix-loophelix factor HES-1 prevents mammalian neural differentiation in the central nervous system. EMBO J. 13: 1799-1805.

Israël, A., O. Yano, F. Logeat, M. Kieran, and P. Kourilsky, 1989. Two purified factors bind to the same sequence in the enhancer of mouse MHC class I genes: One of them is a positive regulator induced upon differentiation of teratocarcinoma cells. Nucleic Acids Res. 17: 5245-5257.

Janknecht, R., C. Sander, and O. Pongs. 1991. (HX)n repeats: A $\mathrm{pH}$-controlled protein-protein interaction motif of eukaryotic transcription factors? FEBS Lett. 295: 1-2.

Kawaichi, M., C. Oka, S. Shibayama, A.E. Koromilas, N. Matsunami, Y. Hamaguchi, and T. Honjo. 1992. Genomic organization of mouse Jk recombination signal binding protein (RBP-Jk) gene. J. Biol. Chem. 267: 4016-4022.

Kieran, M., V. Blank, F. Logeat, J. Vandekerckhove, F. Lottspeich, O. Le Bail, M.B. Urban, P. Kourilsky, P.A. Baeuerle, and A. Israël. 1990. The DNA binding subunit of NF- $\mathrm{KB}$ is identical to factor $\mathrm{KBFl}$ and homologous to the rel oncogene product. Cell 62: 1007-1018.

Le Bail, O., R. Schmidt-Ullrich, and A. Israël. 1993. Promoter analysis of the gene encoding the $I_{\kappa} \mathrm{B} \alpha / \mathrm{MAD} 3$ inhibitor of NF-kB-positive regulation by members of the rel/NF- $\mathrm{B}$ family. $E M B O$ /. 12: 5043-5049.

Locke, J., M.A. Kotarski, and K.D. Tartof. 1988. Dosage-dependent modifiers of position effect variegation in Drosophila and a mass action model that explains their effect. Genetics 120: 181-198.

Maier, D., G. Stumm, K. Kuhn, and A. Preiss. 1992. Hairless, a
Drosophila gene involved in neural development, encodes a novel, serine rich protein. Mech. Dev. 38: 143-156.

Maier, D., B.M. Marte, W. Schafer, Y. Yu, and A. Preiss. 1993. Drosophila evolution challenges postulated redundancy in the E(spl) gene complex. Proc. Natl. Acad. Sci. 90: 5464 5468.

Matsunami, N., Y. Hamaguchi, Y. Yamamoto, K. Kuze, K. Kangawa, H. Matsuo, M. Kawaichi, and T. Honjo. 1989. A protein binding to the $\mathrm{JK}$ recombination sequence of immunoglobulin genes contains a sequence related to the integrase motif. Nature 342: 934-937.

Pollock, R. and R. Treisman. 1991. Human SRF-related proteins: DNA-binding properties and potential regulatory targets. Genes \& Dev. 5: 2327-2341.

Posakony, J.W. 1994. Nature versus nurture: Asymmetric cell divisions in Drosophila bristle development. Cell 76: 415418.

Price, B.D., Z. Chang, R. Smith, S. Bockheim, and A. Laughon. 1993. The Drosophila neuralized gene encodes a C3HC4 zinc finger. $E M B O$ /. 12: 2411-2418.

Sasai, Y., R. Kageyama, Y. Tagawa, R. Shigemoto, and S. Nakanishi. 1992. Two mammalian helix-loop-helix factors structurally related to Drosophila hairy and Enhancer of split. Genes \& Dev. 6: 2620-2634.

Schweisguth, F. and J.W. Posakony. 1992. Suppressor of Hairless, the Drosophila homolog of the mouse recombination signal-binding protein gene, controls sensory organ cell fates. Cell 69: 1199-1212.

1994. Antagonistic activities of Suppressor of Hairless and Hairless control alternative cell fates in the Drosophila adult epidermis. Development 120: 1433-1441.

Simpson, P. 1990. Lateral inhibition and the development of the sensory bristles of the adult peripheral nervous system of Drosophila. Development 109: 509-519.

Smith, D.B. and K.S. Johnson. 1988. Single-step purification of polypeptides expressed in Escherichia coli as fusions with glutathione S-transferase. Gene 67: 31-40.

Tata, F. and D.A. Hartley. 1993. The role of the Enhancer of split complex during cell fate determination in Drosophila. Development (Suppl.) 139-148.

Tun, T., Y. Hamaguchi, N. Matsunami, T. Furukawa, T. Honjo, and M. Kawaichi. 1994. Recognition sequence of a highly conserved DNA binding protein RBP-Jk. Nucleic Acids Res. 22: 965-971. 